\title{
Study of health and nutritional status of the workers working in knitting industry located at K anpur, India
}

\section{M eenaxi Tiwari* and Sudha Babel}

Department of Textiles and Apparel Designing, College of Home Science, Maharana Pratap University of Agriculture and Technology, Udaipur-313001(Rajasthan), INDIA

*Corresponding author. E-mail: meenaxi.tiwari84@gmail.com

Received: April 7, 2013; Revised received:September 14, 2013; Accepted: September 25, 2013

Abstract: Knitting industry occupies a pivotal position in the economic dynamism of various countries. The workers in the knitting industry suffer from various types of health risk factors. The risk in the knitting industry is higher and the ability to control it is lower. The majority of the problems are due to poor work environment, manual work condition and long hours of static working posture in the knitting industry. The present study was conducted to study the health and nutritional status of the workers in knitting industry, located in the city Kanpur, India. Body mass index (BMI) technique was used to study the health and nutritional status of the workers. The 300 workers of knitting industry from four different sectors (spinning, knitting, dyeing, and printing) of the industry who worked in a knitting sector were randomly selected from each unit of industry. The anthropometric measurements viz., height in $\mathrm{cm}$, weight in $\mathrm{kg}$ of each respondent was recorded. The results revealed that the selected sample was suffering from occupational stress and health problems. Out of total 300 workers, majority of the respondents $(22.00 \%)$ were in CED Grade III (Severe) category followed by $16.00 \%$ in CED grade IV (Moderate), $14.00 \%$ in low weight normal, $12.00 \%$ in CED Grade I (Mild), $11.00 \%$ in obese grade I and $10.00 \%$ in obese grade II. Only $17.00 \%$ respondents were observed under normal nutritional status. Thus, the respondents were suffering from occupational stress and health problems.

Keywords: Body mass index, Knitting industry, Nutritional status, Workers health

\section{INTRODUCTION}

Knitting industries is the age old business carried out in India (Singh et al., 2005). It has provided employment for millions of people thus creating a source of earning for poor, illiterate or less educated people (Bamji et al., 1996; Foster and Gariballa, 2005). In the past, the condition of the knitting industries was not up to the mark compared to present industries (Jaiswal, 2011). Poor physical conditions at work, non availability of modernized equipments, low wages and non-supportive management staff worsen the physical and mental health of the workers (Medhi et al., 2006). Nutritional status, health status and occupational stress are distinct but interrelated factors (Sassoon, 2010). Any variation in one factor will affect other two factors. If there is increase in occupational stress it affects nutritional status and in turn create health problem. On the other hand, change in health status predisposes the occupational stress and initiates nutritional problem (Ronnenbeg et al., 2000). Kusumaratna (2002) reported that physical hazard such as inadequate lighting and overheating at several units must receive attention and intervention. The management must be aware that this condition could influence workers productivity and factory production. The amount and ISSN : 0974-9411 (Print), 2231-5209 (Online) All Rights Reserved ๑ Applied and Natural Science Foundation www.ansfoundation.org quality of light at a workplace, walls and work surfaces can influence the health of the people and their job performance. Illumination is one of the critical elements in the design of any workplace, because without adequate lighting, important elements could not be seen correctly. Many studies have indicated interrelation between nutritional status, health status and occupational stress (Singh et al., 2005; Bedi, 2006; Medhi et al., 2006; Kawaharadai et al., 2007). Keeping in view the present investigation was conducted to study the health and nutritional status of the workers working in knitting industry, Kanpur, India.

\section{MATERIALS AND METHODS}

A purposive sample technique was applied to obtained nutritional status of the workers of knitting industry, located at Kanpur, India using body mass index (BMI) technique. A total 300 respondents ( 75 respondents from each unit) were selected form spinning, knitting, dyeing, and printing units of the industry. The respondents were categorized into underweight, normal at risk of obesity and obese categories depending upon the BMI classification given by body mass index was calculated by using height and weight of the respondents. BMI 
provides reasonable indication of the nutritional status. BMI was calculated by dividing the absolute weight $(\mathrm{kg}$.) with absolute height $(\mathrm{m})$ squared as given in the following formula:

BMI $\left(\mathrm{kg} / \mathrm{m}^{2}\right)=$ Weight $(\mathrm{kg}.) / \mathrm{H}$ eight $\left(\mathrm{cm}^{2}\right)$

The values obtained were interpreted as per the classes of BMI suggested by (WHO/IASO/IOTF, 2000). Proposed classification of BMI for adults Asian is given in Table 1.

Anthropometric measur ements

Height : The height of an individual is made up of the sum of four components-legs, pelvis, spine and skull (Jelliffe, 1966).

Techniques: The height was measured using vertical anthropometric rod. The subject was asked to stand erect looking straight on a levelled surface without shoes, with heels together and toes apart. The anthropometric rod was placed behind the subject in the centre of the heels perpendicular to the ground. The sagital plan was placed over the head of the subject, applying a slight pressure to reduce the thickness of the hair. The reading was noted to the nearest of $0.1 \mathrm{~cm}$.

Weight: Body weight is the most widely used and simplest reproducible anthropometric measurements for the evaluation of nutritional status. It indicates the body mass and is a composite of all constituents like, water, minerals, fat, protein etc. (Bamiji et al., 2003)

Technique: A platform spring balance was used for measuring weight. The person was asked to stand in the centre of the platform base feet with minimum clothing and without touching anything else. The measurement was observed to the nearest of $0.50 \mathrm{~kg}$. The balance was standardized and adjusted to zero to avoid error.

\section{RESULTS AND DISCUSSION}

Nutritional status is the level of nutrients in the body and the ability of level to maintain normal metabolic integrity. Nutritional status of a larges population can be assessed quickly by recording anthropometric measurements viz., height, weight, waist and hip circumference, than dietary surveys and clinical assessments (Megied and Abdul, 2007). Weight indicates the body mass and is a composite of all body constituents like water, minerals, fat, protein and bone. It is sensitive to small changes in nutritional status. While height may differ widely among healthy individuals of the same age. It is considered to be good prognostic indicator of health, particularly in severe malnutrition. Height of the individual can be increased by improving nutrition and health care. It is also influenced by standard of living and quality of life (Bamji et al., 1996). BMI acts as an indicator of the nutritional status. It classifieds the nutritional status of the respondents in terms of underweight, normal and at risk of obesity.
Table 1. BMI classification.

\begin{tabular}{llc}
\hline S.N. & Classification & BM I $\left(\mathrm{kg} / \mathrm{m}^{2}\right)$ \\
\hline 1 & Under weight & $<18.50$ \\
2 & Normal range & $18.50-22.90$ \\
3 & Over weight & $=23.00$ \\
4 & At risk & $23.00-24.90$ \\
5 & Obese grade I & $25.00-29.90$ \\
6 & Obese grade II & $>30.00$ \\
\hline
\end{tabular}

In the present study nutritional status of the respondents was assessed by recording height, weight, of the respondents. Using these measurements body mass index (BMI), of each respondent were calculated and categorized depending on the ranges with respect to BMI classification. The result (Table 2) showed that out of 300 respondents of the textile industry, 50 respondents $(17.00 \%)$ were recorded in normal nutritional status, 41 respondents $(14.00 \%)$ under low weight, 34 respondents $(11.00 \%)$ in obese-I category, 30 respondents $(10.00 \%)$ in obese-II category, 35 respondents $(12.00 \%)$ in CED grade I (mild), 46 respondents (16.00\%) in CED Grade IV (moderate) and 64 respondents $(22.00 \%)$ in CED grade III (severe). Among different units of the textile industry in the spinning unit 12 respondents $(16.00 \%)$ were observed in normal nutritional status, 10 respondents (13.33\%) in low weight, obese-II category in CED Grade IV (moderate), 8 respondents $(10.66 \%)$ in obese-I category, $5(6.66 \%)$ in CED grade I (mild) and 20 respondents $(26.26 \%)$ were noted in CED grade III (severe). In the knitting unit of the textile industry, 15 respondents $(20.00 \%)$ were observed in normal nutritional status, 7 respondents $(9.33 \%)$ in low weight, 10 respondents $(13.33 \%)$ in obese-I category, CED grade I (mild) and CED Grade IV (moderate), 8 respondents $(10.66 \%)$ in obese-II category, and 15 respondents $(20.00 \%)$ were noted in CED grade III (severe). Tiwari et al. (2004) reported that out of 514 cotton textile workers of Wardha indicated that obesity were found in majority of workers and was significantly associated with low back pain.

In the dying unit 14 respondents $(18.66 \%)$ were noted in normal nutritional status, 10 respondents $(13.33 \%)$ in low weight, 8 respondents $(10.66 \%)$ in obese-I category, 5 respondents $(6.66 \%)$ in obese-II category, $12(16.00 \%)$ in CED grade I (mild), 14 (18.66\%) and CED Grade IV (moderate) and 12 respondents $(16.00 \%)$ in CED grade III (severe) whereas in the printing unit 9 respondents $(12.00 \%)$ were observed in normal nutritional status, 14 respondents $(18.66 \%)$ in low weight, 8 respondents (10.66\%) in obese-I category and CED grade I (mild), 7 respondents $(9.33 \%)$ in obese-II category, $12(16.00 \%)$ in CED Grade IV (moderate) and 17 respondents (22.66\%) were recorded in CED grade III (severe). Li et al. (2006) 
Table 2. BMI of the respondents in knitting industry ( $\mathrm{N}=300)$.

\begin{tabular}{|c|c|c|c|c|c|c|c|c|c|c|c|}
\hline \multirow[t]{2}{*}{ Classification } & \multirow[t]{2}{*}{ BMI $\left(\mathrm{kg} / \mathrm{m}^{2}\right)$} & \multicolumn{2}{|c|}{$\begin{array}{l}\text { Spinning unit } \\
(n=75)\end{array}$} & \multicolumn{2}{|c|}{$\begin{array}{l}\text { K nitting unit } \\
\qquad(n=75)\end{array}$} & \multicolumn{2}{|c|}{$\begin{array}{l}\text { Dyeing unit } \\
\qquad(\mathrm{n}=75)\end{array}$} & \multicolumn{2}{|c|}{$\begin{array}{l}\text { Printing unit } \\
\qquad(n=75)\end{array}$} & \multicolumn{2}{|c|}{$\begin{array}{c}\text { T otal } \\
(\mathrm{N}=300)\end{array}$} \\
\hline & & $f$ & $\%$ & $f$ & $\%$ & $f$ & $\%$ & $f$ & $\%$ & $f$ & $\%$ \\
\hline $\begin{array}{l}\text { CED Grade III } \\
\text { (Severe) }\end{array}$ & $<16.0$ & 20 & 26.66 & 15 & 20.00 & 12 & 16.00 & 17 & 22.66 & 64 & 22.00 \\
\hline $\begin{array}{l}\text { CED Grade IV } \\
\text { (Moderate) }\end{array}$ & $16.0-17.0$ & 10 & 13.33 & 10 & 13.33 & 14 & 18.66 & 12 & 16.00 & 46 & 16.00 \\
\hline $\begin{array}{l}\text { CED Grade I } \\
\text { (Mild) }\end{array}$ & $17.0-18.5$ & 5 & 6.66 & 10 & 13.33 & 12 & 16.00 & 8 & 10.66 & 35 & 12.00 \\
\hline $\begin{array}{l}\text { Low W eight } \\
\text { normal }\end{array}$ & $18.5-20.0$ & 10 & 13.33 & 7 & 9.33 & 10 & 13.33 & 14 & 18.66 & 41 & 14.00 \\
\hline Normal & $20.0-25.0$ & 12 & 16.00 & 15 & 20.00 & 14 & 18.66 & 9 & 12.00 & 50 & 17.00 \\
\hline Obese Grade I & $25.0-30.0$ & 8 & 10.66 & 10 & 13.33 & 8 & 10.66 & 8 & 10.66 & 34 & 11.00 \\
\hline Obese Grade II & $>30.00$ & 10 & 13.33 & 8 & 10.66 & 5 & 6.66 & 7 & 9.33 & 30 & 10.00 \\
\hline
\end{tabular}

CED- chronic energy deficiency; f-frequency

reported that a long term occupational exposure to cotton dust, acid, caustics and work in dying and printing, jobs in the textile industry will increase risk of chronic energy deficiency in the workers. Nutritional status usually affected by age, educational level, income, work duration in the life span (Foster and Gariballa, 2005). Singh et al. (2005) pointed out that $12 \%$ of textile workers were having severe anaemia and the similar observations were reported by Jaiswal (2011). Traditionally labour-oriented markets are changing towards more automation and mechanization, at the same time general awareness about occupational safety, occupational and environmental hazard is limited in the society. With these structural changes the workers in low resources settings are more likely to be affected by the dangers of high technology than their counterparts in developed countries. Due to lack of education, lack of awareness about the hazards of their occupations, general backwardness in sanitation, poor nutrition and proneness to epidemics aggravate their health hazards in their work environment.

The nutritional status of the respondents was assessed by recording height, weight of the respondents of various units in knitting industry. Using these measurements like body mass index (BMI), of each respondent, it was noted that $26.66 \%$ of the respondents belonged to chronic energy deficiency (CED) grade III of spinning unit followed by $(22.66 \%, 20.00 \%$ and $16.00 \%)$ printing, knitting and dyeing unit (Table 2). The results showed that 18.66 and $16.00 \%$ respondents of dyeing and printing units belonged to CED IV grade of BMI followed by similar percentage of knitting and spinning unit $(13.33 \%)$ respondents. The BMI showed that $16.00 \%$ and $13.33 \%$ workers of dyeing and knitting unit belonged to 17.00 18.50 of BMI categories which represented chronic energy deficient grade I (mild). Few workers of printing and spinning units $(10.66 \%$ and $6.66 \%)$ also belongs to same range $18.66 \%$ and $13.33 \%$ respondents were in the low weight normal range from printing, spinning and dyeing unit. Whereas only one third of respondents belong from normal nutritional status $(20.00 \%)$ from knitting unit followed by dyeing, spinning, and printing unit $(18.66 \%, 16.00 \%$ and $12.00 \%)$. Table 2 also showed that $13.66 \%$ and $10.66 \%$ respondents were found at risk category from knitting, dyeing, spinning and printing unit, while in spinning and knitting units 14.00 and $11.00 \%$ were observed in obese-I and obese-II categories respectively. Furthermore, analysis of table 2 concluded that $22.00 \%$ respondents suffered from CED grade I and $17.00 \%$ were in normal range. Interestingly, it was noted that one fourth workers were in risk category. This may be due to lack of education, unaware of hazards of their occupation, general backwardness in the sanitation, poor nutrition and climatic proneness of this geographic region to epidemics aggravate their health hazards from the work environment. Moreover, nutritional status is the level of nutrients in the body and the ability of levels to maintain normal metabolic integrity (Magied and Abdul, 2007).

\section{Conclusion}

The present study concluded that the selected respondents were suffering from occupational stress and health problems. But it was noteworthy that most of the respondents were having normal nutritional status and nearly one third of them were at risk category. BMI showed that out of total 300 workers, majority of the respondents (22.00\%) were in CED Grade III (Severe) category followed by $16.00 \%$ in CED grade IV (Moderate), $14.00 \%$ low weight normal, $12.00 \%$ in CED Grade I (Mild), $11.00 \%$ in obese grade I and $10.00 \%$ in obese grade II. Only $17.00 \%$ respondents were observed under normal nutritional status. The variety of morbidities detected among knitting workers especially the high prevalence of under nutrition, 
was alarming. Further research on health, nutritional status and occupational stress among workers of different working units of textile industries is required.

\section{REFERENCES}

Bamji, M.S., Rao, N.P. and Readdy, V. (1996). Textbook of human nutrition. Oxford and IBM Publishing Co. Pvt. Ltd., New Delhi, pp. 315-332.

Bedi, R. (2006). Evaluation of occupational environment in two textile plants in northern India with specific reference to noise. Indian J ournal of Health, 44: 112-116.

Foster, S. and Gariballa, S. (2005). Age as a determinant of nutritional status. Nutrition J ournal, 28: 127-139.

Jaiswal, A. (2011). A study of the occupational health function among female textile workers, International J ournal of Sociology and Anthropology, (3):109-114.

Jaiswal, A. (2013). Estimation of stature from hand and phalange length among the among the Santhal Tribe of Odisha, India, anthropological study. Retrieved on March 18, 2013 from http://anthropologicalstudy.blogspot.in

Jelliffe, D.B. (1966). The assessment of nutritional status of community. Monograph Series No. 53, World Health Organization, Geneva.

Kawaharadai, M., Saijo, Y., Yoshioka, E., Sato, T., Sato, H. and Kishi, R. (2007). Relations of occupational stress to occupational class in Japanese civil servants. Indian $\mathrm{H}$ ealth, 45: 247-255.

Kusumaratna, R. (2002). Occupational health and safety profile of a men's underwear factory in Jakarta. J ournal of
Kedokter Trisakti, 21 (2): 52-57.

Li, W., Ray, R.M., Gao, D.C., Fitzgibbons, E.D., Seixas, N.S., Camp, J.E., Wernli, K.J., Astrakianakis, G, Feng, Z., Thomas, D.B. and Checkoway, H. (2006). Occupational risk factors for nasopharynageal cancer among female textile workers in Shanghai, China. Occ. Enviorn. M ed., 63: 39-44.

Magied and Abdul, A. (2007). Assessment of nutritional status of basic school children. J ournal of N utrition, 35: 7.

Medhi, G.K., Hazarika, N.C., Shah, B. and Mahanta, J. (2006). Health problems and nutritional status of tea garden population of Assam. J ournal of M edical Science, 60(12): 496-505.

Ronnenbeg, A.G., Goldman, M.B., Aitken, I.W., Xu, X. (2000). Anemia and deficiencies of foliate and vitamin B-6 are common and vary with season in Chinese women of child bearing age. J our nal of Nutrition, 130: 2703-2710.

Sassoon, J.R. (2010). Diabetes in the elderly and in women. www.pubmed.gov.

Singh, M.B., Fotedar, R., Lakshminarayana, J. (2005). Occupational morbidities and their association with nutritional and environmental factors among textile workers of desert areas of Rajasthan, India. J ournal of 0 ccupational Health, 47: 371-377.

Tiwari, R., Pathak, M.C. and Zodpey, S.P. (2004). Low back pain among textile workers. J . O cc. E nviron. M ed., 7(1): 2729.

WHO/IASO/IOTF (2000). The Asia pacific prospective: Redefining obesity and its treatment. Health communication Australia Pvt. Ltd. 